\title{
Liberalization or Europeanization? The EEC Commission's Policy on Public Procurement in Information Technology and Telecommunications (1957-1984)
}

\author{
Arthe VAN LAER
}

In 1957, the Member States of the European Economic Community (EEC) committed themselves to create a Common Market, which also implied the opening up of public procurement. ${ }^{1}$ For a long time nevertheless they continued to reserve most of their public orders for national firms. From the early 1960s the liberalization of public procurement was debated at the EEC Council, but it only materialized after directives regulating the procedures for the award of public contracts had been adopted. This was the case for public works in 1971 and for public supplies in 1976 only. A directive regulating public procurement in the sectors of water, energy, transport and telecommunications was issued in 1990, whereas public procurement in the sector of services was only regulated in $1992 .^{2}$

Especially in strategic high technology sectors, the EEC governments used public procurement to support indigenous industrial capacity. These national policies did however not prevent Europe from falling technologically behind the United States. In the late 1960s, Europe became dramatically aware of a widening 'technology gap'. In response to this American challenge, the European Commission proposed a common technology policy. ${ }^{3}$ The individual markets of the EEC member states were too small to sustain competitive high tech companies, and not large enough to keep pace with the research and development investments of their American rivals. Economic logic commanded unification of the EEC market. And in the case of high technology products, public orders formed a considerable part of this market. To foster the liberalization of public procurement, the

1. The concept of 'public procurement' covers all purchases of goods or services by national, regional or local authorities. According to the most current interpretation, it also includes procurement by bodies in charge of services of general economic interest (like transport, telecommunications or the production and distribution of water, gas and electricity), whether their legal status is public or private. At the beginning of the 1970s, the total value of this public procurement was estimated at 5 to $9 \%$ of the Community's gross national product: the stakes were quite substantial. See EC COMMISSION, Première communication de la Commission au Conseil sur l'état d'ouverture des marchés publics et des marchés des entreprises chargées d'un service d'intérêt économique général en ce qui concerne les fournitures, SEC/72/2601/final, 24.07.1972, p.5.

2. Council directive 71/305/EEC of 26.07.1971, in: Official Journal of the European Communities, (hereafter $O J$ ), $\mathrm{n}^{\circ} \mathrm{L} 185,16.08 .1971$, pp.5-14; Council directive 77/62/EEC of 21.12.1976, in: $O J$, $\mathrm{n}^{\circ} \mathrm{L} 13,15.01 .1977$, pp.1-14; Council directive 90/531/EEC of 17.09.1990, in: $O J, \mathrm{n}^{\circ} \mathrm{L} 297$, 29.10.1990, pp.1-48; Council directive 92/50/EEC of 18.06.1992, in: OJ, nL209, 24.07.1992, pp.1-24.

3. On the first steps towards a common EEC technology policy, see É. BUSSIÈRE, A. VAN LAER, Recherche et technologie ou la «sextuple tutelle» des États sur «la Commission, éternelle mineure», in: M. DUMOULIN (éd.), La commission européenne (1958-1972), Histoire et mémoires d'une institution, forthcoming 2007. 
Commission could invoke the provisions of the EEC Treaty. But for the Commission this intra-Community liberalization should only be a first step. The American high tech firms benefited not only from a continental private market, the federal government also supported them through huge governmental orders. The EEC should provide European industry with similar support. National preferential procurement had proved too small-scaled to make the difference. But grouped at Community level, public purchases would become a powerful technology policy instrument. The Member States' industrial policies should not simply be abolished, but rather 'Europeanized'. For this second step, the EEC Treaty did however not provide a legal basis, and Member State resistance would prove far greater.

Based on the European Commission's archives, this article will retrace the Commission's attempts to persuade the Member States to liberalize and Europeanize public procurement in two high technology key sectors: information technology and telecommunications. It stops in 1984, towards the end of the Thorn Commission's term of office, when the Commission definitely opted for the liberalization of telecommunications equipment procurement, abandoning the more ambitious goal of Europeanization - as it had already done for information technology. To set the background, a preliminary section will review the Community legislation on public procurement from the EEC Treaty up to $1984 .^{4}$

\section{Community Legislation on Public Procurement (1957-1984)}

The Treaty establishing the EEC did not include any explicit clause on public procurement, but its articles on the free movement of goods and services and freedom of establishment were applicable to public procurement. ${ }^{5}$ They prohibited the Member States from introducing new restrictions and obliged them to eradicate the existing ones progressively. From the beginning of the 1960s onwards, a group of experts from the six member countries studied the approximation of laws concerning public procurement. ${ }^{6}$ Pursuant to the proceedings of this group, the general programmes on the liberalization of establishment and services of

4. This article results from my ongoing doctoral research on the policy of the European Communities in the sectors of information technology and telecommunications (1965-1984), which was financed by a Research Fellowship of the Belgian National Fund for Scientific Research (2000-2004). An earlier version, entitled L'Européanisation des marchés publics dans deux secteurs critiques: l'informatique et les télécommunications (1971-1977) was presented at the conference Politique industrielle communautaire: quelle marge de manæuvre pour les entreprises?, organized by Dr. M. Moguen-Toursel (Louvain-la-Neuve, 13-14 June 2003). The present text has benefited from the constructive comments of an anonymous referee. I would also like to express my gratitude to Ms. J. Collonval, archivist at the European Commission, for her kind and efficient assistance.

5. Especially articles 7, 52-53 and 59-60.

6. The proceedings of this group from 1960 to 1963 are to be found in the Archives of the European Commission in Brussels (hereafter ACOM), BAC118/83/25-27. 
December 1961 laid down the opening up of public works contracts before the end of 1963. By adopting these programmes, the Council also agreed with the principle of coordinating the procedures for the award of public contracts. It seemed unrealistic to standardize the different national procedures, but they had to become more transparent and meet certain objective criteria to make it possible to control whether tenderers were discriminated because of their nationality. ${ }^{7}$

In March 1964, the Commission proposed two directives to the Council concerning public works contracts: the first aimed to open up these contracts, the second to coordinate their award procedures. For every public contract above a certain threshold, the award procedure had to respect three principles: the contracting authorities were required to publish a notice in the Official Journal of the European Communities containing all information necessary to potential tenderers; the tender dossier could not hold discriminatory technical specifications; finally, the contracts had to be awarded following fixed criteria. Among the tenderers whose economic, financial and technical capacities were verified, the contract had to be granted to the one offering the lowest price. Three tender procedures would be authorized: the open tender, the restricted tender (a notice calls for candidates to participate, only a selection of these candidates may tender) and, under specific conditions, the negotiated tender (the contract is negotiated between the contracting authority and one or more tenderers). A parallel decision would create an Advisory Committee, composed of representatives of the Member States and presided over by the Commission, which would examine all problems raised by the application of the directives.

Discussions at COREPER were laborious and lengthy: the Council adopted the directive coordinating the procedures for the award of public works contracts only in July 1971. The principal amendment to the Commission's proposal was the exclusion from the directive's scope of the bodies producing or distributing water and energy, or supplying transport and telecommunications services. This exclusion was due to the difference of legal status of these bodies: the semi-public or private organizations in certain Member States would have been exempt from the directive, whereas their public counterparts in other countries would have been included. Beyond this legal justification, the exception for these sectors stemmed above all from the Member States' determination to maintain their control on important public works contracts. ${ }^{8}$

7. Programme général pour la suppression des restrictions à la libre prestation des services, in: OJ, n², 15.01.1962, pp.32-35; Programme général pour la suppression des restrictions à la liberté d'établissement, in: $O J, \mathrm{n}^{\circ} 2,15.01 .1962$, pp.36-45; Bulletin quotidien Europe, $\mathrm{n}^{\circ} 1153$, 22.12.1961, p.4.

8. On the COREPER negotiations: ACOM, BAC118/83/16-18. The directive concerning the co-ordination of procedures for the award of public works contracts: Council directive 71/305/EEC of 26.07.1971, in: $O J, \mathrm{n}^{\circ} \mathrm{L} 185,16.08 .1971, \mathrm{pp} .5-14$. Another directive was adopted to abolish the restrictions on the free access to public works markets (Council directive 71/304/EEC of 26.07.1971, in: $\left.O J, n^{\circ} \mathrm{L} 185,16.08 .1971, \mathrm{pp} .1-4\right)$, but it only confirmed the existing situation since the transition period for the liberalization of intra-Community trade had in the meantime expired. Its principal interest remained in defining the concept of 'public works'. The decision setting up the Advisory Committee: Council decision 71/306/EEC of 26.07.1971, in: $O J$, n $^{\circ} \mathrm{L} 185,16.08 .1971, \mathrm{p} .15$. 
In the meantime, all the public supplies ${ }^{9}$ contracts were in principle liberalized thanks to two Commission directives of December 1969. The first recognized the reservation of these contracts for national firms as measures having an effect equivalent to quantitative restrictions. These 'measures' were defined very broadly: they comprised not only "legal, regulatory and administrative arrangements", but also "the administrative practices and all acts emanating from a public authority, including incentives". So the directive also applied to the very numerous national preferences not formalized by law, or even by any written document at all. The second directive of December 1969 ended the transition period for the removal of measures having an effect equivalent to quantitative restrictions. ${ }^{10}$ Without the harmonization of the procedures for the award of public contracts, however, it remained impossible to check compliance with these new directives. After the conclusion of the discussions on the public works directive, the Commission submitted a similar proposal for public supplies in March 1971. ${ }^{11}$

In spite of a declaration of intent by the heads of State or government at the Paris conference in October 1972, ${ }^{12}$ and notwithstanding the fact that the proposed directive on supplies was based on the same principles as the works directive already adopted by the Council (notably, it excluded from the start the bodies administering transport or telecommunications services, or producing and distributing water or energy), it took five more years before its approval in December 1976. ${ }^{13}$ As a consequence of the Community enlargement, the discussions at COREPER only started in the beginning of 1974. They concerned principally five issues. The first question was whether preferences granted as part of a regional policy would be allowed. These regional preferences were finally

9. The term 'supplies' covers a wide variety of items, from everyday provisions like the heating of public buildings or foodstuffs for hospitals to capital goods such as the installations of power stations or railway equipment. Military supplies were of course not affected by the Community legislation.

10. Commission directive 70/32/EEC of 17.12.1969, in: OJ, n ${ }^{\circ} \mathrm{L} 13,10.01 .1970$, pp.1-3; Commission directive 70/50/EEC of 22.12.1969, in: $O J$, $^{\circ} \mathrm{L} 13,19.01 .1970$, pp.19-31 (translated citation).

11. Proposal for Council directive (submitted by the Commission to the Council on 15.03.1971), in: $O J, \mathrm{n}^{\circ} \mathrm{C} 50,22.05 .1971, \mathrm{pp} .15-23$. On the timing of the proposal: EC COMMISSION, Rapport général sur l'activité des Communautés en 1970, n4, Luxembourg, 1971, §66.

12. EC COMMISSION, Rapport général sur l'activité des Communautés en 1972, n6, Luxembourg, $1973, \S 5$.

13. Council directive 77/62/EEC of 21.12.1976, in: $O J$, $\mathrm{n}^{\circ} \mathrm{L} 13,15.01 .1977$, pp.1-14. The directive was accompanied by a resolution concerning the access to Community public supply contracts for products originating in non-member countries (Council resolution of 21.12.1976, in: $O J, \mathrm{n}^{\circ} \mathrm{C} 11$, 15.01.1977, pp.1-2), a Commission statement concerning Article 115 of the Treaty (in $O J, \mathrm{n}^{\circ} \mathrm{C} 11$, 15.01.1977, p.2), a Council resolution concerning the review of the directive (Council resolution of 21.12.1976, in: $\left.O J, \mathrm{n}^{\circ} \mathrm{C} 11,15.01 .1977, \mathrm{p} .3\right)$ and a Council statement concerning the bodies responsible in the Member States for providing telecommunications services (in $O J, \mathrm{n}^{\circ} \mathrm{C} 11$, 15.01.1977, p.3). Decision 71/306/EEC concerning the Advisory Committee for Public Contracts was also modified (Council decision 77/63/EEC of 21.12.1976, in: $O J$, n $^{\circ} \mathrm{L} 13,15.01 .1977, \mathrm{p} .15$ ). The reports of the COREPER discussions on the directive are in ACOM, BAC118/83/157-159. The negotiations until late January 1976 are summarized in ACOM, BAC118/83/205, Council note, 107/76(ES9), 29.01.1976. 
authorized provided that the invoked regulation was compatible with the Treaty; they would only be excluded in 1992. Secondly, there was disagreement about the safeguard measures against the application of the directive to products originating in third countries and put in free circulation in one of the Member States. After painstaking negotiations all delegations agreed on an official declaration by the Commission, in which it confirmed its intention to authorize the exclusion of these goods from the directive by means of article 115 of the Treaty. The third subject of dispute was the application of the directive in the case of an international agreement between a Member State and a third country on a joint project. The supplies intended for such a project were excluded from the directive, but had to be presented to the Advisory Committee for Public Contracts, which would also deal with supplies as of 1977. The fourth topic was the level of the threshold: it was ultimately laid down at 200000 European units of account. ${ }^{14}$ Finally, there were important debates about the appropriateness of including data processing and telecommunications. The Commission's project of directive had made no exception for these sectors, but they became both excluded in the definitive version. The positions of the Commission and the Member States on this matter can only be understood against the light of their recent experiences with public procurement of data processing and telecommunications equipments. The Member States had rejected the Commission's proposals to group these public purchases at Community level, and they practized with varying success national preferences.

\section{Public High Technology Procurement: The Commission Proposes to 'Buy European'}

In 1967, the Commission put forward a new idea in the Medium-Term Economic Policy Committee: ${ }^{15}$ public orders of technologically advanced products including informatics and telecommunications - should be opened up, but only to European tenderers. ${ }^{16}$ The creation of a large common market was an absolute necessity. The OECD studies on technology gaps had actually confirmed that the size of the market was an essential factor in explaining the difference in performance between the United States and Europe. ${ }^{17}$ Pulling down the borders within the Community would stimulate the creation of continental-scale firms, whose financial capacities would allow the investments in research and development which were essential in order to remain in the front line. The elimination of redundancies would, moreover, permit the Community industry to

14. In 1977,1 European unit of account was worth $0,65 £$.

15. This committee, composed of top level officials from the Member States, had been set up by the Council in April 1964. Its mission was the definition of a five-year programme to co-ordinate the economic decisions of Member State governments and Community institutions. EEC COMMISSION, Rapport général sur l'activité de la Communauté en 1965, n8, Luxembourg, 1966, § 137. 
specialize and to concentrate all their efforts in research and development on a limited number of products.

The Commission however had come to the conclusion that a common market alone would not suffice to take up the 'American challenge'. The American firms benefited indeed not only from a continental private market, but also from a large 'artificial' market consisting of massive public orders. Some European governments also tried to support national high-tech industries through public procurement, but the volume of their contracts remained too small to enable these firms to keep pace with American competitors. The only way to provide the European industry with important public orders was to replace the national preferential procurement policies by a European preference. The Community denounced the 'Buy American Act' at the OECD and the GATT. ${ }^{18}$ But at the same time the Commission recommended the EEC Member States to adopt this American model at Community level, at least for the high technology sectors.

A European preference in public procurement would raise important questions. In the first place, it would have to be defined which firms are 'European': ${ }^{19}$ a delicate task, because thereby would show "all political, legal and economic questions that determine the Community's relations with third countries". ${ }^{20}$ Firms located outside the EEC territory were clearly not European. But what about those situated inside the Community, but financed by foreign capital? The Treaty of

16. When not specified otherwise, this part is based on ACOM, BAC118/83/198, working document of the Commission [for the Council group of officials for industrial policy], 13781/III/70, [27.07.1970]; ACOM, BAC118/83/198, secretariat of the Medium-Term Economic Policy Committee (hereafter indicated by its French acronym CPEMT), draft summary of the discussions on the question of concerted public procurement in the CPEMT Sectorial Structural Policy Group, ORII/196/69, 09.09.1969; ACOM, BAC118/83/197, note by the Commission's special Scientific and Technical Research Group, EUR/C/433/68, 29.01.1968; note (translated) from I. Schwartz to T. Vogelaar, 14.02.1968; note [by DG IV/dir. B/div. 1], IV/2/4583/68, 22.03.1968; M. Lacotte to P. Pujade, 17.01.1969; note by DG XII/Dir. B/div. 2 [written by M. Lacotte], 14.01.1969; Commission to CPEMT Scientific and Technical Research Policy Group, 4066/III/69, 13.02.1969 (distributed on 4 June to the Commission members as document SEC/69/2119); note by DG II/ Dir. B, 06.02.1969 and (translated) note by H. Michaelis, 08.02.1969 (these last two documents present DG II and DG XII's comments on a draft version of note 4066/III/69).

The Commission proposed this policy particularly for the following products: air navigation instruments, radio-navigation instruments, telecommunication equipment, electronic didactical materials, scientific and measurement instruments, railway signs, railway equipment, data processing systems, large electrical equipment, meteorological equipment and medical instruments. ACOM, BAC118/83/198, DG III to CPEMT Sectorial Structural Policy Group, 21971/III/69, 28.11.1969.

17. Cf. EC COMMISSION, Rapport général sur l'activité des Communautés en 1969, n³, Luxembourg, 1970, §5.

18. Cf. ACOM, BAC138/92/355, note by [T. de Corné], annex to P. Schlösser to R. Toulemon, no date, concerning the 02-06.02.1970 session of the OECD Trade Committee.

19. Besides the documents cited in footnote 16 , this definition problem is dealt with in ACOM, BAC118/83/197, note by the Commission's special Scientific and Technical Research Group, EUR/C/365/68, 24.01.1968.

20. Translated quotation from ACOM, BAC118/83/197, note by H. Michaelis, 08.02.1969. 
Rome regarded every firm with offices registered in the EEC as a 'Community' firm. Politically, however, it was difficult to recognize as such the European subsidiaries of American multinationals as IBM. Lastly, there was the case of true Community firms that employ foreign technology. For instance, the informatics subgroup of the Medium-Term Economic Policy Committee ${ }^{21}$ discussed whether Siemens was really a Community firm, bearing in mind that the Siemens computers were manufactured under licence from the American RCA. The debate seemed rather theoretical, however: there was a broad consensus to include these firms in Community protectionism. The acquisition of existing technologies was indeed viewed as a necessary step towards developing more advanced technologies.

Besides the definition of the beneficiary firms, a method had to be devised to favour these firms in the award of public contracts without violating the Treaty of Rome. In 1968, the Approximation of laws direction from the Commission's Competition Directorate-General drew up a detailed report on this problem. ${ }^{22}$ It firstly dismissed a certain number of solutions: a protectionist commercial policy against high-tech imports, an unofficial agreement that the Treaty would not be applied to the subsidiaries of foreign firms, the use of article 235 or a very broad interpretation of certain Treaty clauses. From a legal point of view, the most appropriate procedure for according a European preference in public procurement appeared to be the grouping of all the Member State orders. The Treaty aimed in fact to prevent discrimination against tenderers who did not share the nationality of the contracting authority. If the contracts were awarded jointly by the EEC Member States, the interests of all European firms would be sufficiently guaranteed by the representation of their government in the contracting body. Thus, all risks of undue favours to the firms of one Member State were basically precluded, and there would be no grounds for including these orders in the forthcoming directives concerning the procedures for the award of public contracts. Other Commission documents claimed that the objective of concerted public procurement being the Community interest, it could be anyway legitimized by article 90 of the Treaty, even if it implied restrictions on intra-Community trade. ${ }^{23}$

In the Commission's view, the principal goal of the concerted or grouped high technology orders would be to enhance the international competitiveness of European industry. Potential financial advantages for the public buyers were only of secondary importance. Common public procurement had to complete common subsidies for research projects, by creating outlets for the developed technologies. These purchases could also concern already marketed products of the subsidized firms. The orders should in any case be large enough to enable these companies to produce greater quantities and thus become cost-effective. In order to increase the grouped orders, it was also considered to encourage the participation of private

21. On this Subgroup, see A. VAN LAER, Endeavours to build European Computers, 1965-1974: An Opportunity to develop an EC Industrial Policy?, in: L. HEIDE, R. WILSON (ed.), History and Technology, forthcoming.

22. Ibid., note [by DG IV/dir. B/div. 1], IV/2/4583/68, 22.03.1968.

23. ACOM, BAC $138 / 92 / 355$, P. Schlösser to R. Toulemon, no date. 
buyers by means of fiscal favours. If important orders were moreover spread over long periods, the firms could also better plan their activities. It was even envisaged to grant temporarily extra high prices, but the Commission thought that it would in most sectors be possible to encourage competition between a couple of large companies, in imitation of the big American Federal agencies. The Commission felt that these public agencies set the technical and economic requirements for their orders so high that "the artificial market thus created constitutes a kind of super-market where the laws of competition rule with even more stringency than in private markets". ${ }^{24}$ Furthermore, selection criteria related to the financial and technical capacities of tenderers should promote industrial concentration and specialization. In addition, Commission officials also thought about compensating European firms that would not benefit from these high technology purchases by the preferential award of other orders, but this scenario appeared quite incompatible with the Treaty. Regarding the practical organization of the concerted or grouped orders, different options were considered. However, it was clear that the methods should be differentiated according to the sector and devised in close consultation with both public purchasers and industry.

The major problem of concerted public orders would however be the "juste retour" to each Member State. The Commission was fully aware that the EEC formed a single entity only in principle: "At the present stage of European integration, it would not be realistic to ignore the need to respect a certain geographical equilibrium in the overall distribution". ${ }^{25}$ This arrangement would be easier if it embraced all the products of a given sector, or even all high technology sectors. It would also be preferable to place orders with a multinational European consortium, rather than with a company of a single nationality. The systematic use of subcontractors would further increase the number of beneficiaries of the grouped public orders.

The idea of a European preference in the public procurement of advanced technology seems to have been instigated in the Commission by the Industrial affairs Directorate-General and by the special Scientific Research Group. ${ }^{26}$ Considering internal correspondence and records of inter-service meetings - often at the level of directors or directors-general - this objective was however shared by

24. Translated quotation from ACOM, BAC118/83/197, Commission to the CPEMT Scientific and Technological Research Policy Group, 4066/III/69, 13.02.1969.

25. Translated citation from ibid. This statement was also incorporated in a draft version of the Commission memorandum on a common industrial policy (COM/70/100/final, 18.03.1970), but modified subsequent to ACOM, BAC138/92/355, note by [T. de Corné], annex to P. Schlösser to R. Toulemon, no date.

26. The Commission's special Scientific and Technical Research Group was a small task force composed of the officials P. Maillet, M. Albert and P. Bourguignon. It was established following the Council resolution on a common research policy of 31 October 1967, in order to prepare the activities of the CPEMT Scientific and Technological Research Policy Group until the new single Commission organized its General Research and Technology Directorate-General. ACOM, procès-verbal of the 19-23.11.1967 Commission session, COM/67/PV15/final/1st part, 13.12.1967. 
all Directorates-General involved: Industrial Affairs, Research, Economic and Financial Affairs, Competition and Internal Market and Approximation of Laws. The Commission's suggestion was also quite positively received by the Member States' officials in the Medium-Term Economic Policy Committee. In the second Medium-Term Economic Policy Programme (1968), they explicitly stated that concerted procurement policies could be taken into consideration for at least some high technology fields. ${ }^{27}$ Concrete projects for concerted public purchases were most advanced in the Medium-Term Economic Policy Committee's Informatics Subgroup. From 1967, this subgroup studied the construction of a very large calculator by a consortium of the main European firms, and projected that the European governments would not only support the development of this machine, but also ensure a minimum market. ${ }^{28}$

In March 1970, the Commission formally proposed concerted public procurement for high technology products in its memorandum to the Council on the industrial policy of the Community. ${ }^{29}$ The Member States' representatives in COREPER discussed this memorandum for more than a year, but they did not reach a common position. One of the reasons for this failure was a difference of views on the role of public procurement: France wanted to use public procurement to stimulate the high-tech industries, while the Federal Republic of Germany preferred liberalizing these markets and supporting European industries by means of research and development subsidies. ${ }^{30}$ In practice, however, the national policies of the Member States converged very broadly (cf. part III below), so the significance of this ideological opposition should probably not be exaggerated. Another point of controversy was the stance to be taken towards firms from third countries, and especially towards American firms. More essentially, most Member States appeared not to be disposed to transfer new powers to the Community. ${ }^{31}$ In the meantime, the first project that should have led to grouped public orders - the construction of a very large calculator - had been abandoned. ${ }^{32}$

27. EC COMMISSION, Projet de second programme de politique économique à moyen terme (présenté par la Commission au Conseil), COM/68/148/final, 20.03.1968.

28. ACOM, BAC118/83/197, note by the Commission's special Scientific and Technical Research Group, EUR/C/433/68, 29.01.1968; draft note [by D. Verdiani], 2434/III/69, 27.01.1969; ACOM, BAC130/83/197, report from the Informatics Subgroup to the CPEMT Scientific and Technological Research Policy Group, 4445/III/69/revision 2, 05.03.1969.

On the activities of this Informatics Subgroup, see footnote 21.

29. EC COMMISSION, La politique industrielle de la Communauté. Mémorandum de la Commission au Conseil, COM/70/100/final, 18.03.1970.

30. EC COMMISSION, Rapport général sur l'activité des Communautés en 1972, n6, Luxembourg, 1973, § 291; interview with R. Perissisch (former chief of cabinet of Commissioner Spinelli), Rome, 07.11.2003.

31. Cf. interpretations of top level Commission officials: R. TOULEMON, J. FLORY, Une politique industrielle pour l'Europe, PUF, Paris, 1974 (SUP, L'économiste, 40), pp.110-113; C. LAYTON, The High-Tech Triangle, in: R. MORGAN, C. BRAY (ed.), Partners and Rivals in Western Europe: Britain, France and Germany, Gower, Aldershot-Brookfield, 1986, pp.184-204.

32. ACOM, BAC422/95/44, minutes of the 20.11.1970 session of the COST Informatics Group, COST/82/70, 30.11.1970. 


\section{The Commission's Analysis of National Preferences in Computer and Telecommunications Equipment Procurement}

While the discussions on a European preferential public procurement policy for high technology were going on, the Commission tolerated the existing national preferences in public data processing procurement. The sector was judged to be of strategic importance and, in view of IBM's dominant position on the EEC market, support to the indigenous European industry appeared quite indispensable. The Commission tried, however, to be well informed about the form and the extent of these preferences. Both France and Germany had foreseen preferential public procurement in industrial policy programmes for their national computer firms. The German programme formulated the preference in a subtle way, and the Commission did not object. Along with the German computer programme, the Commission also kept an eye on the company Datel, created in 1970: as the Federal Post Office held $40 \%$ of its capital, it seemed likely that the postal services would rent their computers from Datel. This follow-up did however not lead to any Commission action. As the first "Plan Calcul" implied a very extensive preference for national products, the Commission drew the French authorities' attention to the fact that this preference was contrary to the Treaty, and asked them not to continue with it after the end of the programme. When France nevertheless renewed the preference in 1971 as part of the second Plan Calcul, the Commission confined itself again to a warning, anxious not to complicate the negotiations on the proposed public supplies directive. The Commission also monitored the Dutch preference for Philips and, finally, the data processing procurement policy in Belgium. In 1969, the Belgian government entered into contracts with Siemens and Philips whereby each of them would get $25 \%$ of all public computer orders over five years, amounting to a minimum rental value of 65 million Belgian francs. This arrangement would have been settled in return for industrial plants in Belgium. The case was a source of great irritation to the Competition Directorate-General, mainly because the Belgian government disregarded its repeated requests for more details. $^{33}$

33. On the national preferences: ACOM, BAC138/92/357, DG IV/dir. D/div. 3, report of the 10.01.1972 multilateral meeting concerning national aids to the computer sector, 33/IV/72, no date; P. Mathijsen to DG III, DG XIV and the Legal service, 22.03.1972; P. Mathijsen to DG III and Legal service, IV/D/3/72/423, 22.04.1972; ACOM, BAC138/92/355, director-general of DG III [R. Toulemon, written by T. de Corné] to Much, III/A/3/4663, 05.08.1971; draft note for the Commission, annex to a letter from the Director [of DG III/dir. A, written by T. de Corné] to P. Bourguignon, 02.02.1973; French permanent representation to EC Commission, 10.08.1972.

Specifically on the French programmes: ACOM, BAC138/92/357, minutes of the 20.03.1969 multilateral meeting on French aids in the field of electronic computers, 7748/IV/69, no date.; draft communication to the Commission, circulated for comments to the services concerned by $\mathrm{P}$. Mathijsen (note IV/D/3/70/900 of 25.03.1970); director-general of DG III [R. Toulemon] to W. Schlieder, III/A/5/72/4371, 26.04.1972; note by DG XI/dir. A/div. 1, 05.11.1973. Specifically on the Belgian case: ACOM, BAC118/83/200, P. Mathijsen to the director-general of DG XI [F. Braun], 20.03.1974. 
Analyzing the effectiveness of national protectionist practices, the Commission came in the early 1970s to the conclusion that their impact was rather limited: the Community market remained dominated by IBM (cf. figure 1). Only the British support measures for ICL appeared to have achieved some success. ${ }^{34}$ The Commission did not manage to collect data on public computer purchases, but it found information on the computer stock of the French and German administrations (figures 2 and 3). The share of the different computer producers was comparable to their share of the total market (figure 1), whereby the American firms, and especially IBM, predominated.

Figure 1: Market share of the different computer manufacturers in the EEC, the United Kingdom and the United States in June 1969 (in \% of values)

\begin{tabular}{|l|r|r|r|r|r|r|}
\hline & \multicolumn{1}{|c|}{ FRG } & Benelux & France & \multicolumn{1}{c|}{ Italy } & \multicolumn{1}{c|}{ UK } & \multicolumn{1}{c|}{ USA } \\
\hline IBM & 63.3 & 59.0 & 62.6 & 66.3 & 40.3 & 71.0 \\
Honeywell Bull & & & & & & \\
GE & 7.0 & 14.8 & 16.2 & 22.6 & 6.5 & 6.1 \\
Univac & 7.1 & 5.9 & 4.5 & 7.5 & 3.8 & 7.0 \\
CDC & 2.7 & 3.0 & 3.1 & 1.5 & 0.9 & 5.3 \\
ICL & 0.7 & 3.1 & 1.7 & 0.2 & 42.0 & - \\
Philips & - & 5.5 & - & - & - & - \\
Siemens & 13.2 & 2.5 & 1.0 & 0.8 & - & - \\
CII & 0.3 & 1.2 & 4.0 & - & - & - \\
Other & 5.7 & 5.0 & 6.9 & 1.1 & 6.5 & 10.6 \\
\hline Total & 100.0 & 100.0 & 100.0 & 100.0 & 100.0 & 100.0 \\
\hline
\end{tabular}

Figure 2: Manufacturers of operational computers in France on 1 January 1970: total and governmental and semi-governmental markets (in \% of numbers)

\begin{tabular}{|l|r|r|r|}
\hline & \multicolumn{1}{|c|}{ IBM } & \multicolumn{1}{c|}{ Bull-GE } & \multicolumn{1}{c|}{ Other } \\
\hline Total market of which & 48.0 & 32.0 & 20.0 \\
\hline - EdF, GdF and CEA & 37.0 & 16.5 & 46.5 \\
\hline- Public organisms & 43.0 & 29.0 & 28.0 \\
\hline
\end{tabular}

34. Cf. ACOM, BAC31/84/35, note by DG III/dir. D/div. 1, 13.12.1971. 
Figure 3: Origin of operational computers in public administration, research and education in the Federal Republic of Germany on 1 January 1971 (in value $)^{35}$

USA

FRG

Other
1.23 billion $\mathrm{DM}$

0.33 billion $\mathrm{DM}$

0.14 billion $\mathrm{DM}$

The situation of telecommunication equipment was quite different. The Commission did not get precise information about intra-Community trade ${ }^{36}$ but the collation of production and trade figures gave an approximate picture (figure 4). Intra-Community commerce was equally limited, but the telecommunications equipment was almost exclusively supplied by national firms, and not by third country companies as in the data processing sector.

Figure 4: Share of intra-Community imports in the visible consumption of telecommunication equipment in five ${ }^{37}$ Community countries in 1969 (in millions $\$)^{38}$

\begin{tabular}{|l|lr|}
\hline Production & 1508.5 \\
\hline Imports & 88.2 & \\
\hline - of which intra-EEC & & \\
\hline Exports & 333.0 \\
\hline - of which intra-EEC & & 68.5 \\
\hline Visible consumption & 1263.7 \\
\hline$\%$ of imports in visible consumption & $7 \%$ & \\
\hline - of which intra-EEC & & $3.5 \%$ \\
\hline
\end{tabular}

To the Commission's knowledge, none of the Member States adopted regulations to exclude foreign suppliers from its telecommunication markets. The sector's particular features accounted for the poor trade figures. The telecom markets were dominated in each country by a single buyer, the Postal and

35. Source of figures 1-3: EC COMMISSION, Première communication de la Commission au Conseil sur l'état d'ouverture des marchés publics et des marchés des entreprises chargées d'un service d'intérêt économique général en ce qui concerne les fournitures, SEC/72/2601/final, 24.07.1972, pp.17 and 19.

36. On the difficulty of obtaining figures: ACOM, BAC31/84/35, note by DG III/dir. D/div. 1, 13.12.1971.

37. The Netherlands were not covered because data were incomplete.

38. Source: EC COMMISSION, Première communication de la Commission au Conseil sur l'état d'ouverture des marchés publics, op.cit., p.37. 
Telecommunications Administration (PTT), which dealt with a small number of specialized national firms. Over the years, connivances had been forged between the PTT administrations and their traditional suppliers. There were moreover important technical barriers for foreign suppliers. The technical characteristics of telecommunication networks differed greatly from one country to another, in spite of the recent harmonization efforts of the European Conference of Postal and Telecommunications Administrations (known under its French acronym as CEPT). The EEC Commission itself by the way had proposed in 1968 to accelerate the standards harmonization at Community level and to create for this purpose a EEC Post and Telecommunications Committee, composed of Member State officials. This proposal had however remained without effect. ${ }^{39}$

\section{The 1976 Supplies Directive: Information Technology and Telecommunications Excluded}

Faced with the inefficiency of the current national preferences and the impossibility of a European preference, the Commission concluded in the early 1970s that the European high-tech industries should at least have the benefit of a common market. Its proposal for a directive on public supplies contracts therefore made no exception for data processing and telecommunications. In a communication to the Council on the state of public procurement issued in 1972, the Commission emphasized on the contrary that procurement for high technology products, which depended essentially on public or semi-public orders, remained much more fragmented than for ordinary commodities. For products that did not depend exclusively or primarily on public orders, 15 to $35 \%$ of Community consumption already involved trade between the Member States. For telecommunications equipment, the rate of intra-Community trade was estimated at only $3.5 \%{ }^{40}$

In the Industrial affairs Directorate-General, the division in charge of the computer sector however believed, that it would damage the Community industry if the directive applied immediately to the whole sector. The European computer firms should first gain a competitive position thanks to a common industrial policy. In the opinion of the Directorate-General's officials,

39. EC COMMISSION, Première communication de la Commission au Conseil sur l'état d'ouverture des marchés publics, op.cit., pp.36-43; ACOM, BAC118/83/208, C. Layton to F. Braun, [October 1974]; EC COMMISSION, Rapport général sur l'activité des Communautés en 1968, n², Luxembourg, 1969, $\$ 80$.

40. Proposal for Council directive (submitted by the Commission to the Council on 15.03.1971), in: OJ, $\mathrm{n}^{\circ} \mathrm{C} 50$, 22.05.1971, pp.15-23; EC COMMISSION, Première communication de la Commission au Conseil sur l'état d'ouverture des marchés publics, op.cit., pp.16-19. 
"without such a framework, it would be difficult to ask the Member States to relinquish certain measures that are contrary to the Treaty but are de facto justified by external competitive pressure". 41

In 1973, while preparing proposals for a common computer policy, the Industrial affairs Directorate-General seems to have sounded out once more informally the position of the Member States as regards a European preference for public procurement in this sector. ${ }^{42}$ The Council resolution on a common computer policy of 15 July 1974 invited the Commission to present proposals for, among other measures, a collaborative procurement policy. ${ }^{43}$ The German delegation at COREPER had still specified that, in its government's view, this resolution did not prejudge the application of the public supplies directive to the computer sector. ${ }^{44}$

During COREPER's first discussions on the directive, Germany, Denmark and Ireland declared themselves favourable to the inclusion of the data processing sector, whereas the United Kingdom, France and Italy were radically opposed. Belgium and the Netherlands wished to link the application of the directive to the development of the European computer policy. According to the Industrial affairs Directorate-General's wishes, the Commission's delegation also adopted this last standpoint. In November 1974, it proposed that the directive would immediately cover those categories of equipment that did not need a transition period, and at the latest in 1980 the entire computer sector. In the meantime, the Commission could propose to the Council that the directive be extended to further types of equipment. Because the evolution of the computer industry was very difficult to anticipate, the Commission suggested to introduce the possibility of postponing the 1980 deadline by a Council decision taken on a proposal from the Commission. ${ }^{45}$ During the transition period, the Member States could continue to use direct award procedures. In principle, they still had to respect the Treaty's non-discrimination rules. But to rally the British, Italian and French governments to this compromise, the Commission guaranteed them informally that it would not object to their national

41. ACOM, BAC138/92/355, P. Schlösser [written by T. de Corné] to J. Flory and P. Bourguignon, 10.01.1972; draft note to the Commission, annex to a letter from the Director [of DG III/dir. A], written by T. de Corné] to P. Bourguignon, 02.02.1973; ACOM, BAC118/83/208, note [by J. Quequin], 10.10.1974; citation translated from ACOM, BAC138/92/355, P. Bourguignon to P. Schlösser, 21.01.1972.

42. ACOM, BAC138/92/355, draft questionnaire on the computer sector [established by DG III/dir. D/ div. 1], 03.01.1973. We did not come across the final questionnaire, nor possible replies.

43. Council resolution of 15.07 .1974 concerning a common data processing policy, in: $O J, \mathrm{n}^{\circ} \mathrm{C} 86$, 20.07.1974, p.1.

44. ACOM, BAC64/86/55, extract from the draft summary minutes of the 733rd COREPER meeting on 19-21 and 25.06.1974, 1435/74(RP/CRS22)Extr.1, 19.11.1974.

45. ACOM, BAC118/83/200, working document of the Commission services (for the Council Economic Questions Group), annex to C. Struxiano to F. Braun et al., 27.11.1974; ACOM, BAC118/83/205, Council note, R/T/668/74(ES), 27.11.1974; BAC118/83/200, C. Struxiano to F. Braun, 17.12.1974; ACOM, BAC118/83/205, Council note, 107/76(ES9), 29.01.1976. 
preferences until the end of the transition period, ${ }^{46}$ even if they were clearly discriminatory. ${ }^{47}$ Finally, all data processing equipment remained outside the scope of the directive until 1 January 1981 - the date fixed in the final version of the directive - but this exception would not be extended.

Telecommunications caused even more difficult negotiations, ${ }^{48}$ and in the end the bodies operating in this sector were not subjected to the directive. From the start, the British delegation asserted that the Post Office, a 'nationalized corporation', could not fall within the scope of the directive. The Italian delegation also maintained that its mixed telecommunications sector, only public in part, should not be included either. So both of them invoked the legal arguments that had served to exclude the water, energy and transport services. Fundamentally, they contended that their telecommunication offices had received a special status precisely to escape from bureaucratic burdens and to be able to operate with the flexibility of private business. The Commission replied that the British and Italian authorities still widely intervened in the functioning of these firms. Nor were there any insuperable legal obstacles: it would suffice if the directive stipulated that in the field of telecommunications, private-law legal persons act as contracting authorities. The other Member States approved the application of the directive to telecommunication services, on condition that the British and Italian telecommunication offices were likewise incorporated, in order to ensure genuine reciprocity.

46. ACOM, BAC118/83/200, anonymous note, 17.03.1976. The United Kingdom accepted the compromise before the end of 1975, Italy and France in early 1976. Cf. ACOM, BAC118/83/205, Council note, 107/76(ES9), 29.01.1976. On the understanding with France, also: ACOM, BAC118/83/200, J. Loeff to W. Schlieder and F. Braun, 10.03.1976; ACOM, BAC138/92/357, annotation by Beaufine on a transmission note from Hecht to É. Brackeniers dated 01.12.1976.

47. According to a Commission document, the French support programme to the company CII-Honeywell-Bull assured for the period 1976-1980 purchases by the public sector amounting to 4050 million French francs. Moreover, if the orders remained more than 5\% under the yearly objective, CII-Honeywell-Bull would receive compensation for 55\% of this difference. ACOM, BAC118/83/200, W. Schlieder to DG III and DG XI, 02.03.1976.

48. About the negotiations on the subject of telecommunications: ACOM, BAC118/83/209, C. Struxiano to F. Braun, 12.03.1974; draft note annexed to C. Struxiano to I. Schwartz and B. Harris, 07.06.1974; C. Struxiano to F. Braun, I. Schwartz, J.-P. Derisbourg and B. Harris, 08.11.1974; ACOM, BAC118/83/208, C. Struxiano to F. Braun, I. Schwartz and B. Harris, 12.08.1974; ACOM, BAC138/92/353, report from the Commission to COREPER, III/876/2/74, 30.09.1974, called the 'Layton report'; Council note, 1936/74(ES160), 30.10.1974; note by the secretariat general about the 763rd COREPER meeting on 12.03.1975, SI(75)173, 15.03.1975; ACOM, BAC118/83/200, working document from the Commission (to the Council Economic Questions Group), annex to C. Struxiano to F. Braun e.a., 27.11.1974; C. Struxiano to F. Braun, 17.12.1974; ACOM, BAC118/83/205, Council note, 107/76(ES9), 29.01.1976; note by the secretariat general about the 818th deputy COREPER meeting on 18.06.1976, SI/76/510, 23.06.1976; ACOM, BAC118/83/210, C. Struxiano to F. Braun, I. Schwartz, B. Harris, J.-P. Derisbourg and É. Brackeniers, 17.03.1976; EC COMMISSION, Harmonisation des services et des matériels de télécommunications (Communication de la Commission au Conseil), COM/75/109/final, 12.03.1975. 
There was also, however, a crucial practical impediment to the liberalization of telecommunications equipment: the multiplicity of technical standards would deprive a European invitation to tender of any significance. The Commission admitted that the unification of these standards would be necessary to fulfil the directive's purpose totally. Moreover, it considered that common standards would boost the European industry's position on the global marketplace. But the Commission did not want to subject the directive's application in the field of telecommunications to the adoption of uniform technical standards. On the contrary, the directive would bring about an economic incentive to harmonization and innovation. ${ }^{49}$

In March 1974, Commissioner Altiero Spinelli brought together for the first time the top officials in charge of the telecommunication services in the EEC Member States. A few months later, COREPER mandated the Commission's Industrial affairs Directorate-General to set up a working group of national officials with the aim of drawing up a report on the problems posed by the inclusion of the telecommunications sector, apart from the legal aspects. The 'Layton report' (named after the Commission director chairing the group) was presented to the Council in September 1974. It concluded that the opportunities of competition were too limited because of the different standards, and that the directive should therefore not apply immediately to telecommunications equipment. The working group proposed taking up technical harmonization within the framework of CEPT, which should for this purpose develop a new association with the Community and, as far as possible, also with the telecommunications industry. CEPT also comprised non-EEC states, but the telecommunications network did not in any case stop at the Community borders. The voluntary application of standards practised by CEPT seemed the most efficient procedure to begin with, on account of the high speed of technical change and the slow speed of Community procedures. Before the 'Cassis de Dijon' judgement in 1979 and the adoption of a 'new approach' to technical harmonization in 1985, the sole Community method for removing technical obstacles to trade remained the harmonization of Member State laws. Hence, the Layton report advised common standards to be adopted by CEPT, possibly to be confirmed later by a Community directive. If new equipment was developed to comply with these common standards, it would become all the more important to avoid the distortion of competition through differentiated financing of research and development. For some members of the Layton group, this problem had to be solved through the coordination, or even the grouping of national subsidies at Community level. Finally, all delegations, except the British, agreed that, provided there were certain amendments and accompanying measures, aside from juridical considerations, there was no reason that telecommunications should be definitively excluded from the directive.

49. ACOM, BAC118/83/209, draft memo from the Commission [written by C. Struxiano] to the Council Economic Questions Group, 04.04.1974. 
Late in 1974, the Commission proposed a scenario to COREPER, in line with the Layton report, for the gradual application of the directive to the telecommunications sector. The directive would directly cover equipment non-specific to telecommunications, as well as radio and television equipment, and be extended to specific equipment before 1 January 1979, following a calendar established by the Council on the proposal of the Commission. In this perspective, the Council had to pass a resolution immediately, without awaiting the adoption of the directive, defining the necessary harmonization activities and specifying that these activities might be entrusted to CEPT, where the Commission would be henceforth represented. A concurrent declaration would require, during the transition period, that the contracting authorities put at the Community tenderers' disposal any information needed to offer specific equipment as soon as it would fall within the scope of the directive. The Commission accepted an amendment put forward by Germany: the expansion of existing equipment or installations would be exempt from the directive if a change of supplier would mean disproportionate technical difficulties.

Germany, France, Ireland, Denmark and the Netherlands were willing to accept the Commission's proposal to apply the directive progressively to the telecommunications sector, but still under the strict condition that it would concern the telecommunications services of all Member States, irrespective of their legal status. At the Commission's request, in 1975, the CEPT agreed to take on the harmonisation work. ${ }^{50}$ The United Kingdom and Italy held to their position however, now joined by Belgium: the directive should not affect their national telecommunications services. The question of the inclusion of telecommunications became one of the final problems to be solved before the adoption of the directive.

Internal documents reveal that, in view of the British and Italian opposition, the Commission had abandoned any hope of including telecommunications in the directive as early as mid-1975; it continued to plead this case only for tactical motives. Conversely, the French and especially the German delegation persevered. According to a Commission memo, Germany's persistence was due to its ministry of Economic affairs, which wanted to thwart the collusion which was noticed between the Postal ministry and the firm Siemens. This conflict between the postal administration and the ministries of Economy and Finance was thought to exist in most Member States. ${ }^{51}$ In the end, the bodies responsible for providing telecommunications services were excluded from the directive's scope. At the request of Germany and France, a simultaneous Council statement recognized however the need to draw up measures to liberalize procurement by telecommunications bodies. It invited the Commission to follow up the

50. The Council has never formally adopted a resolution to this effect, because the Commission had anticipated its decision and contacted the CEPT to ensure that the question could be discussed at the CEPT meeting of April 1975. Cf. ACOM, BAC138/92/355, note by the Secretariat General on the 764th deputy COREPER meeting on 19.03.1975, SI/75/204, 21.03.1975.

51. ACOM, BAC118/83/210, C. Struxiano to F. Braun, I. Schwartz, B. Harris, J.-P. Derisbourg and É. Brackeniers, 17.03.1976. 
harmonization work of the CEPT, and to propose, within two years, a schedule of liberalization measures. ${ }^{52}$

\section{The early 1980s: \\ European Integration in the Context of International Liberalization}

Following the adoption of the public supplies directive, the Commission set out to prepare the future opening of public procurement in the excluded high-tech sectors. But intra-Community liberalization was only a first step in the Commission's opinion. In February 1979, a Commission inter-service group on 'Public procurement preferences' concluded:

"A 'national' preference could certainly be understood, for some time, by the concern to favour first the creation of European industries in the considered field. But it should for all that not be forgotten that every efficient 'national' preference leads to the isolation of the national market under consideration. The concentration and specialization of European industry, necessary to become competitive in at least some sectors, are thereby more and more affected. It follows that the abolition of national preferences is essential, but their immediate replacement by Community preferences is appropriate". ${ }^{53}$

Catching up with American and Japanese industry was high on the Jenkins Commission's agenda. And the Commission wanted to use public technology procurement as an innovation policy instrument - as the American and Japanese authorities did - but at Community, rather than national level. ${ }^{54}$

The Commission's proposal for a four-year programme for the data processing sector, adopted by the Council in 1979, envisaged the following joint actions in the field of public procurement: the adoption of efficient methods for a rapid introduction of common technical standards, the unification of requirements and evaluation criteria, common actions to prepare the European industry for future liberalization, measures encouraging the purchase of indigenous European material if the price and performance were comparable to other offers and, finally, the identification of projects of common interest that could be financed by Community subsidies. ${ }^{55}$ The study of these questions was assigned to a 'Public Procurement Subcommittee' of the Advisory Committee for the Management and Coordination of Data Processing Programmes, composed of senior officials from the EC Member States and chaired by a Commission representative.

52. $O J, \mathrm{n}^{\circ} \mathrm{C} 11,15.01 .1977, \mathrm{p} .3$.

53. ACOM, BAC26/84/14, A. Mattera, final report of the interservice Public Procurement Preferences Group, 09.02 .1979 (translated quotation).

54. ACOM, BAC81/85/59, draft Commission communication to the Council, A Policy for Industrial Innovation - Strategic Lines of a Community Approach, 21.09.1981.

55. Commission proposal for Council decision of 08.11.1976, in: $O J, \mathrm{n}^{\circ} \mathrm{C} 39,16.02 .1977$, pp.2-8; Council decision 79/783/EEC of 11.09.1979, in: OJ, nº231, 13.09.1979, pp.23-28. 
In its first year, the Public Procurement Subcommittee examined particularly the possibilities of harmonizing the clauses of data processing contracts and applying in public orders the technical standards adopted by its fellow Standardization Subcommittee. Uniform contract conditions and standards in the public sector would not only cover a substantial part of the information technology market, they would also set an example to the private sector. Besides the Commission wanted to prepare common specifications and evaluation criteria. It suggested for instance that all Member States should favour plugable material and buy their large computers and terminal equipment separately, in order to create opportunities for the European industry, which was stronger in the second segment. They should prefer purchase to leasing contracts, which were advantageous to the American firms with greater financial capacities. And they should communicate as soon as possible their procurement plans to all European firms, in order to permit them to prepare themselves. The Commission also proposed that the Member States exchange information about the products of their national firms. However, the Commission's ideas went too quickly and too far for the Member States. The Subcommittee concentrated mainly on contractual clauses and standardization, and even on these topics it did not arrive at any concrete actions. The activities of the Subcommittee were indeed stopped in 1977 , due to a lack of personnel at the European Commission. ${ }^{56}$

The supplies directive's exception for data processing procurement was planned to expire in January 1981. As this deadline approached, the Commission was preparing a new Community strategy for the information technology sector, in close dialogue with the twelve principal European firms, brought together in the so-called 'Roundtable'. The Roundtable members pleaded not only for the creation of a homogenous European market, but also for the reservation of this market to European manufacturers, excluding the subsidiaries of American companies. They agreed on the abolition of national procurement preferences on condition that they would be replaced by a European preference. However, such a European preference was incompatible with the application of the supplies directive. The Commission sympathized with the Roundtable's point of view, but saw insurmountable obstacles to an extension of the directive's transition period for data processing supplies. Following the Tokyo Round in 1979, the Community had approved a GATT code on public procurement, ${ }^{57}$ whereby it committed itself to opening up public procurement as from January 1981. During the negotiations, one of the Community's concessions had been the inclusion of data processing equipment. A

56. BAC26/84/14, Houldsworth, report on the first year's activities of the Public Procurement Subcommittee of the Advisory Committee for the Management and Coordination of Data Processing (hereafter PPSC), III/546/77, 16.11.1977; BAC40/87/1, J.-M. Cadiou to the future members of the PPSC, 18.05.1982; BAC40/87/2, M.S. Audoux, working document for the PPSC, PPSC N18, 21.03.1983.

57. The GATT agreement had come into effect in the EEC following Council decision 80/271/EEC of 10.12.1979 (OJ, n ${ }^{\circ} \mathrm{L} 71,17.03 .1980$, p.44); Council directive 80/767/CEE of 22.07.1980 (OJ, $\mathrm{n}^{\circ} \mathrm{L} 215,18.08 .1980, \mathrm{pp} .1-28$ ) adjusted directive 77/62/CEE to the new code. 
Community request to postpone the GATT code's application to this sector would certainly provoke general protest from the other signatories, and it appeared very unlikely that they would grant the Community a significant delay. A prolonged exclusion of data processing equipment from the EEC supplies directive would thus result in an unacceptable situation: the EEC Member State markets would be open to American and Japanese competition but closed to Community competition. The supplies directive was therefore extended to the data processing sector as planned, in January 1981.

However, the Commission drew the Roundtable's attention to interesting margins for manoeuvre in the GATT code and the EEC directive. Both allowed a specific supplier to be contracted directly in certain cases, such as procurement with national security implications, the order of prototypes, the purchase of a product on which the supplier held exclusive rights or an emergency situation. The Commission suggested that it would adopt a very flexible interpretation of these exceptions. A Commission official reassured the Siemens representative even more generally:

"You and I both know that evaluation procedures and subjective judgement play a powerful role in deciding computer purchases. Moreover, in this sector, we recognize that there is a problem of unbalanced competition. In this respect, though it is not possible to make public statements about the matter, the Commission will continue to encourage European Governments to give European-based companies the best possible chance". ${ }^{58}$

The GATT agreement and the application of the supplies directive to informatics meant, however, that it was no longer possible to make explicit preferential arrangements in informatics procurement. It also seemed that international data processing standards would offer the EEC industry the best prospects; the GATT agreements on standards and technical barriers limited anyway the extent to which measures like type approval could overtly discriminate. Preferential procurement and standards being put aside, research and development subsidies appeared the most appropriate way to strengthen the European industry in the future. At the Commission's initiative, the Community launched several actions to this effect in the early 1980s, the principal one undoubtedly being the ESPRIT programme. ${ }^{59}$

While the Commission only reluctantly supported international procurement liberalization, it was genuinely committed to the creation of a single Community market for data processing equipment. In December 1982, it again convened the Public Procurement Subcommittee of the Advisory Committee for the Management and Coordination of Data Processing Programmes. The

58. ACOM, BAC26/84/14, E. Previdi to P. Cecchini, 08.05.1980 and annexed draft note by C. Struxiano for the Roundtable, 05.05.1980; BAC26/84/14, F. Braun [written by C. Layton] to É. Davignon, 15.01.1980 and annexed draft letter by C. Layton to W. Heimann, [mid-January 1980] (source of quotation).

59. ACOM, BAC81/85/56, note by [C. Layton], 24.03.1981; BAC81/85/61, [A. Riotte], report of a meeting of the 'New information technology' correspondents on 28.04.1981, 05.05.1981. 
Subcommittee resumed its discussions on the harmonization of contractual clauses and the application of common standards in public orders, but failed to produce tangible measures. The Commission again did not succeed in putting the coordination of requirement specifications on the agenda. ${ }^{60}$ Even the implementation of the supplies directive in the data processing sector appeared quite inadequate during the early years. In the Public Procurement Subcommittee the Commission expressed on several occasions its concern about the low number of tenders announced in the EEC Official Journal, the biased wording of some notices and the extensive use of single or negotiated tendering procedures. ${ }^{61}$

In compliance with the Council's statement of 1976 on the liberalization of telecommunications procurement, the Commission invited the heads of the EEC telecommunications administrations to assist it in devising appropriate measures as early as February 1977. It was decided to set up a working group, which held four two-day meetings before the end of the year. The group examined the current telecommunications procurement practices in the Member States, as well as the procedural and other problems that would be posed by the application of the supplies directive. Its final report noted the principal obstacles to public and open invitations to tender in the telecommunications sector: the technical specificity of the national systems, the administrations' awareness of the technical and financial liability of their customary suppliers, the privileged relations created by the public funding of these suppliers' research and development, as well as the political will to support the national industry in order to maintain an independent high-tech capacity in this strategic field or to preserve employment. ${ }^{62}$

In 1980, the Commission recommended to the Council a liberalization plan for terminal equipment, a market which presented both important growth perspectives because of the introduction of telematic terminals, and a unique opportunity for harmonization with the development of the new integrated services data networks. After a three-year trial period, the Member States should have opened at least 10\% of their invitations to tender for terminal equipment to all Community suppliers. This proposal was however blocked by France, which wanted to strengthen its industry first. ${ }^{63}$

Towards the end of 1981, the Industry commissioner Étienne Davignon advocated a more radical European public purchasing policy in those areas where the prudent, regulatory approach had failed: their opening should be facilitated by grouping the purchasing authorities in a European body. And he singled out the telecommunications sector as offering the best chances for such a "quantum jump". The new telecommunications technologies, especially satellite communications

60. ACOM, BAC40/87/1-6.

61. BAC40/87/2, C. Roberts, report of PPSC meeting on 24.03.1983, PPSC N21, 31.05.1983; BAC40/ 87/10, Commission document for the PPSC, CC84/4, 05.12.1984.

62. ACOM, BAC40/87/8, report of the working group 'Opening up of supplies purchases by bodies operating in the field of telecommunications', III/105/78, 04.01.1978.

63. EC COMMISSION, Recommendations on Telecommunications (presented by the Commission to the Council), COM/80/422/final, 01.09.1980; ACOM, BAC81/85/56, note by C. Garric, no date. 
and integrated digital networks, should from the start be ordered through a European agency rather than by the national telecommunications administrations individually. The telecommunications sector was not yet covered by the GATT rules, but there was considerable American pressure to include it in the very near future. In view of this likelihood, it was necessary to prepare European industry for increased competition, and public purchases on a European scale appeared the most effective way to create large and strong European enterprises. ${ }^{64}$ Just as in the early 1970s, however, the EEC governments discarded the option of grouped Community procurement. There was above all fundamental disagreement on the principle of a European preference: only France and Italy supported the Commission's vision, the other member countries preferred international liberalization. ${ }^{65}$

The Commission took a new initiative in the field of telecommunications in 1983. The value of public supplies contracts in the excluded sectors telecommunications, transport, water and energy - had increased and was said now to exceed the value of the covered contracts. Experts estimated the cost of the persistent fragmentation of public procurement - the 'cost of non-Europe' - at 40 billions European units of account. The fast pace of innovation in telecommunications technology made it increasingly difficult to write off research and development costs on the basis of the limited national markets. And the external pressures to liberalize the sector mounted: the revision of the GATT procurement code was foreseen for the end of the year. ${ }^{66}$ In this context, the Commission prudently suggested in June that a group of top level Member State officials be set up to examine a possible Community policy on telecommunications. It also submitted proposals for a series of liberalization measures in September. In agreement with the new group of officials, the Commission drew up a coherent action plan for the sector in the following months and presented it to the Council in May 1984. The action plan took up again the recommendations made in 1980 to

64. BAC81/85/59, [W. Kist], report of the Market working group [of the permanent nucleus for Innovation], 10.07.1981; BAC81/85/60, R. Appleyard to the permanent nucleus of directors-general 'Industrial Innovation', XIII/81/D/6182, 13.11.1981; EC COMMISSION, Mandat du 30 mai 1980. Pour développer l'industrie en Europe: une stratégie communautaire (Communication de la Commission au Conseil), COM/81/639/final, 23.10.1981; ACOM, BAC10/ $85 / 38$, speaking and defensive briefs for É. Davignon at a ministers of Industry meeting (London, 10.12.1981), no date; note by DGIII/F/3 [written by C. Wilkinson], 02.02.1982; ACOM, BAC81/ 85/56, [C. Wilkinson] to the directors-general of Industry, 01.02.1982; ACOM, BAC40/87/1, F. Braun to É. Davignon and K.-H. Narjes, 11.03.1982; ACOM, BAC10/85/487, note on É. Davignon's intervention at the Industry Council of 04.05.1982, 26.04.1982.

65. ACOM, BAC81/85/56, note by C. Day, 09.04.1981; C. Wilkinson, report on the Ministers of Industry meeting of 13.01.1982, 21.01.1982; ACOM, BAC10/85/38, [M. McLaughlin], report on directors-general of Industry meeting of 12.02.1982, 19.02.1982; BAC141/89/76, note from the secretariat general to the Commission members, SI/82/313, 30.04.1982; F. Braun to É. Davignon and K.-H. Narjes, 10.05.1982.

66. BAC40/87/1, F. Braun to É. Davignon and K.-H. Narjes, 11.03.1982; BAC40/87/6, note [by J.-F. Marchipont], 22.12.1983; EC COMMISSION, Communication de la Commission au Conseil. Marchés publics de fournitures. Constat et orientations, COM/84/717/final, 17.12.1984. 
create a common market for telecommunications: technical standardization and liberalization of carriers' purchases, to begin with terminal equipment. To avoid diverging technical options in the future, it also proposed to set up a common reflection framework on the development of new services and to promote common infrastructure projects. The idea of grouped EEC procurement with a preference for European suppliers was definitively abandoned. A huge common research programme, modelled on the ESPRIT programme for information technology, should instead enhance the technological capacities of the European telecommunications industry and thus reinforce its competitive position. This last suggestion would evolve in the RACE programme. ${ }^{67} \mathrm{~A}$ common telecommunications policy finally started to get off the ground, yet the liberalization of telecommunications procurement would only be initiated in 1988, when the Commission issued itself a directive on terminal equipment markets by virtue of article 90 of the EEC Treaty. ${ }^{68}$

\section{Conclusion: the European Commission as an Advocate of Liberalization in two High Tech Sectors}

The opening up of EEC public technology procurement was exclusively founded on 'negative' integration: the abolition of any discrimination against foreign suppliers. The European Commission proposed a 'positive' approach on several occasions: public orders had to be grouped at Community level, reserved for the indigenous European industry and used to pursue industrial policy objectives. The grouped contracts had especially to stimulate the creation of large-scale transnational firms, and to permit them to finance the research and development of front-end technologies. However, this option was rejected by the Member States, who clung to their national technology policies. Confronted with the Member States' resistance, the Commission tended progressively towards a minimalist policy of liberalization: European industry should at least benefit from a large market. The Commission did not abandon the project of a common technology policy, but would henceforth rather turn to large research programmes to support the European industry. To force through public procurement liberalization, the

67. EC COMMISSION, Télécommunications (Communication de la Commission au Conseil), COM/ 83/329/final, 08.06.1983; Communication de la Commission au Conseil sur les télécommunications. Lignes d'action, COM/83/573/final, 29.09.1983; Communication de la Commission au Conseil sur les télécommunications. État d'avancement de la réflexion et des travaux dans ce domaine et premières propositions d' un programme d'action, COM/84/277/final, 18.05.1984.

68. Commission directive 88/301/EEC of 16.05 .1988 on competition in the markets in telecommunications terminal equipment, in: $O J, \mathrm{n}^{\circ} \mathrm{L} 131,27.05 .1988$, pp.73-77. For an analysis of this Commission initiative, see S.K. SCHMIDT, Liberalisierung in Europa. Die Rolle der Europäischen Kommission, (Schriften des Max-Planck-Instituts für Gesellschaftsforschung, Köln, 33), Campus, Frankfurt am Main-New-York, 1998. 
Commission could invoke the EEC Treaty. The American pressure for international procurement liberalization and the changing economic ideology blow further wind in the Commission's sails.

The EEC Member States accepted relatively easily the liberalization of data processing procurement. After a four-year transition period the 1976 directive coordinating the award of public supplies contracts was extended to this sector as from 1981. The success of American firms, and particularly IBM, had indeed already seriously limited the effect of national preferences and imposed de facto technical standards. The case of telecommunications was quite different: the European suppliers still enjoyed a real monopoly on their national markets, protected by technical barriers. In this sector, opening up public procurement was likely to provoke substantial reorganization, and the Member States proved fare more reluctant. To trigger the liberalization of telecommunications procurement, the Commission would in the end have to adopt a directive itself. 